\section{LITERATURE CITEI}

Bonner, J. T., K. K. Kane, And R. H. LeveY. 1956. Studies on the mechanism of growth in the common mushroom, Agaricus campestris. Mycologia 48: 13-19.

Buller, A. H. R. 1933. Researches on fungi. Vol. 5. Longmans, Green and $\mathrm{Co}$., New York and London.

Corner, E. J. H. 1932. The fruit-body of Polysticlus xanthopus Fr. Ann. Bot. 46: 71-111.

DeBary, A. 1887. Comparative morphology and biology of the fungi, mycetozoa and bacteria. Clarendon Press, Oxford.

Gaumann, E. A., and C. W. Dodge. 1928. Comparative morphology of fungi. McGraw-Hill, New York.

Harley, J. L., C. C. McCready, J. H. Brierley, and D. H. Jennings. 1956. The salt absorption of excised beech mycorrhizas. II. The relationship between oxygen consumption and phosphate absorption. New
Phytol. 55: 1-28.

KarPeChenko, G. D. 1928. Polyploid hybrids of Raphanus sativus L. $\times$ Brassica oleracea L. Zeit. Indukt. Abstam. and Vererbungsl. 45: 1-85.

LitTtlefield, L. J., R. D. Wilcoxson, and T. W. Sudia. 1963. Translocation in sporophores of Lentinus tigrinus related to specialized cells. (Abstr.) Phytopathology 53: 881 .

Plunkets, B. E. 1958. Translocation and pileus formation in Polyporus brumalis. Ann. Bot. 22: 237-249.

Roberts, O. 1950. Translocation in fungi. (Abstr.) Proc. VII Int. Bot. Congr. 453-454.

Schutte, K. H. 1956. Translocation in fungi. New Phytol. 55: $164-182$.

SNIDER, P. J. 1959. Stages of development in rhizomorphic: thalli of Armillaria mellea. Mycologia 51:693-707.

Teixeira, A. R. 1962. The taxonomy of the Polyporaceac. Biol. Rev. 37: 51-81.

Amer. Jour. Bot. 52(6): 605-610. 1965.

\title{
THE NATURE OF THE WALI BETWEEN GENERATIVE AND VEGETATIVE NUCLEI IN THE POLLEN GRAIN OF TRADESCANTIA PALUDOSA ${ }^{1,2}$
}

\author{
Keizo Maruyama, ${ }^{3}$ Helen Gay, and Berwind P. Kaufmann \\ Cytogenetics Laboratory, Carnegie Institution of Washington, \\ and \\ Departments of Botany and Zoology, \\ The University of Michigan, Ann Arbor, Michigan
}

\begin{abstract}
A B S T R A C T
Electron-microscopical studies have revealed the existence of a true cell wall-probably containing cellulose and pectin-between generative and vegetative nuclei in the pollen grain of $T$. paludosa. The wall is formed by the fusion of pectin vesicles and becomes continuous at the time of its formation with the intine of the pollen-grain coat. Coincidentally, the inner and outer plasma membranes bordering the newly formed cell wall participate in formation of the plasma membranes of the vegetative and generative cells. Attention is directed to the possible role of the cell wall in facilitating, within the closed system afforded by the pollen grain, the pattern of differentiation that serves to determine the structural and functional properties of the vegetative and generative cells.
\end{abstract}

IN THE MICROSPORE of an angiosperm such as Tradescantia, the haploid nucleus resulting from the two meiotic divisions undergoes a post-meiotic mitosis to give rise to the vegetative and generative nuclei. This is a differential mitosis, which is initiated by positioning of the prophase nucleus close to the heavy or dorsal wall-originally the inner wall at the time of formation of the quartet of microspores (Sax, 1935). Evidence of differentiation is apparent soon after completion of the

1 Received for publication September 17, 1964.

2 This study was supported in part by Research Grants GB-290 from the National Science Foundation and GM10499 from the National Institutes of Health, U. S. Public Health Service.

${ }^{3}$ Present address: Institute for Virus Research, Kyoto University, Kyoto, Japan. mitosis, when the peripherally-lying generative nucleus begins to follow a developmental pathway unlike that of the more centrally located vegetative nucleus. In the course of differentiation, the vegetative nucleus enlarges more or less equally in all diameters to form a spherical unit in which the chromosomes attain the diffuse state that bespeaks high metabolic activity, whereas the generative nucleus elongates more or less unidirectionally to form a cylindrical unit in which the chromosomes remain more condensedassumedly in preparation for the ensuing division that will give rise to the two male nuclei.

Differential mitoses are not uncommon in nature (Ris, 1955), but the microspore division is of particular interest because it occurs within a "closed system," whose contents have become insulated 
from those of other similar cells by the formation of a thick, bilamellate pollen grain wall. One important consideration in this frame of reference is the question whether an isolating barrier in the form of a cell wall exists between generative and vegetative nuclei as they begin to differentiate. An answer in the affirmative has been found in this study, which is based primarily on electronmicroscopical analyses of the fine structure of the microspores of the spiderwort, Tradescantia paludosa.

Materials AND MEthods-Pollen grains at various stages of development-as determined by cytological examination of the pollen, or morphological identification of bud characteristics-were preserved for electron microscopy. A special technique for fixation was utilized to obviate the poor preservation that is frequently encountered when anthers are processed in toto. The following method keeps the pollen grains together in one mass and prevents their desiccation, since they are encased between two layers of agar.

A $2 \%$ aqueous solution of agar was made in a container heated to $90 \mathrm{C}$ in a water bath. When cooled to $40 \mathrm{C}$, this agar solution was used to facilitate fixation of the pollen grains. A layer about $2 \mathrm{~mm}$ thick was spread on a microscope slide; the pollen grains were immediately pressed from the anther onto the agar and then covered with another layer of the agar solution. From this agar sandwich, when it had cooled, a small block enclosing the pollen was cut out. It was lifted from the slide and placed in the fixative, which was a $5 \%$ aqueous solution of $\mathrm{KMnO}_{4}$, where it remained for $2 \mathrm{~min}$. The 6 anthers of each bud (or those remaining after others had been sampled to determine the approximate stage of development) could be processed within 3 to 5 minutes. Little time was lost, therefore, in preserving all the microspores in a given bud.

Following fixation, the material was rinsed in $30 \%$ alcohol and dehydrated through a graded series of ethyl alcohols. The agar blocks containing the pollen grains were embedded in an Epon mixture (Luft, 1961) composed of Epon 812, dodecenyl succinic anhydride (DDSA) and methyl nadic anhydride (MNA) in a ratio of $7: 6: 4$ with $1.5 \%$ tridimethyl phenol (DMP-30) as an accelerator. Ultrathin sections were cut with an LKBUltratome and were examined with an RCA EMU3G microscope.

Results-As the two daughter nuclei are formed toward the end of the microspore mitosis in the pollen grain of T. paludosa, there appears in the equatorial zone of the spindle a series of "electron-lucent" vesicles interspersed with tubules or vesicles of the endoplasmic reticulum (Fig. 1). By analogy, these electron-lucent vesicles may be equated with "pectin vesicles," similar to those that lead to wall formation in meristematic roottip cells (Becker, 1938; Porter and Machado, 1960). In the latter study, vesicles of Allium cepa, which were assumed to contain pectin, were identified at the electron-microscopical level of resolution as electron-lucid cisternae lying in the equatorial region. In appearance they differed strikingly from the vesicles of the endoplasmic reticulum.

The "pectin vesicles" detected in the microspore of $T$. paludosa fuse shortly after their production to form a continuous layer between the two nuclei (Fig. 2). In cross section, this layer is seen to be made up of two dense lines, each about $80 \mathrm{~A}$ thick, and a middle lighter zone, about 300 $500 \mathrm{~A}$ in width. The middle layer, almost entirely devoid of electron-scattering material, can readily be distinguished from the cisternae of the endoplasmic reticulum, which contain some densely electron-scattering materials. It thus appears that a "wall" is formed by fusion of the pectin vesicles. This wall bends downward around the generative nucleus and establishes contact with the intine, or inner layer, of the pollen-grain coat. The region of contact is conspicuously deltoid-like, as is clearly shown in Figure 3 (see also fig. A, Plate 3 , in Kaufmann et al., 1961, where a preliminary report of this study was presented). Figure 3 also shows that when contact is established, the two dense layers bordering the fused pectin vesicles become continuous with the plasma membrane, to establish the membrane of the generative cell on one side of the newly formed cell wall, and the membrane of the vegetative cell on the other side.

Although the intine appears to be almost "empty" (electron-lucent), it shows a marked positive reaction to the periodic-acid Schiff (PAS) test of Hotchkiss (1948) when fairly thick sections $(0.5-1.0 \mu)$ are tested. For this reason the intine is assumed to be composed of substances containing the 1,2 glycol groups for which the test is specific. These substances are probably pectin and cellulose. Evidence for the presence of cellulose has been obtained by application of the iodine-potassium iodide-sulfuric acid test. The intine then appears as a bright-blue layer, and in favorable preparations the wall surrounding the generative nucleus is revealed as a thin blue line. Visualization is probably enhanced and identification facilitated by swelling of the cellulose in the test solution.

As described by Sax and Edmonds (1933), the location of the generative nucleus depends on the position of a given pollen grain in the quartet of microspores, and the prescribed maneuvers of the large cytoplasmic vacuole. The cell wall described in the present paper is laid down close to the generative nucleus which lies near the dorsal wall of the pollen grain. A very thin investment of cytoplasm surrounds the nucleus of the generative cell at the time of formation of the cell wall, but the vegetative cell obtains the vacuoles and almost all of the cytoplasm of the microspore.

As development of the pollen grain proceeds, the cell wall becomes detached from the intine of the 

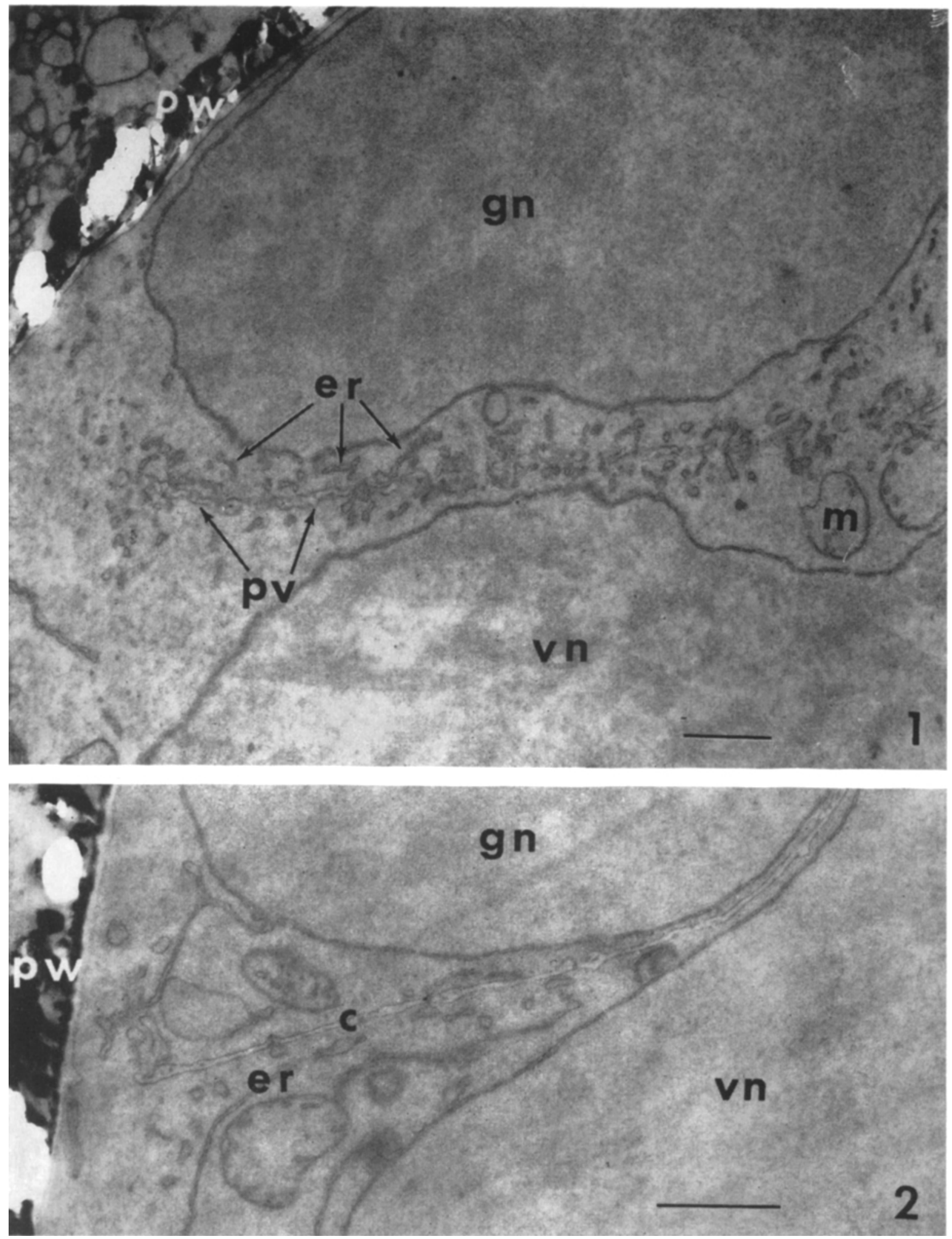

Fig. 1-2.- Fig. 1. Telophase of microspore mitosis of Tradescantia paludosa. The pectin vesicles (pv) are intermingled with short vesicular cisternae of the endoplasmic reticulum (er) and are lined up in the equatorial region between the generative nucleus (gn) and the vegetative nucleus (vn). The contents of the pectin vesicles appear less dense than those of the endoplasmic reticulum. $\mathrm{pw}=$ pollen wall; $\mathrm{m}=$ mitochondrion. $\times 14,000 .-$ Fig. 2 . Late telophase of the microspore mitosis. The pectin vesicles have fused to form a layer (c) whose contents are less electron-dense (electron-lucid) than those of the endoplasmic reticulum. Other symbols as in Fig. 1. $\times 20,000$. 

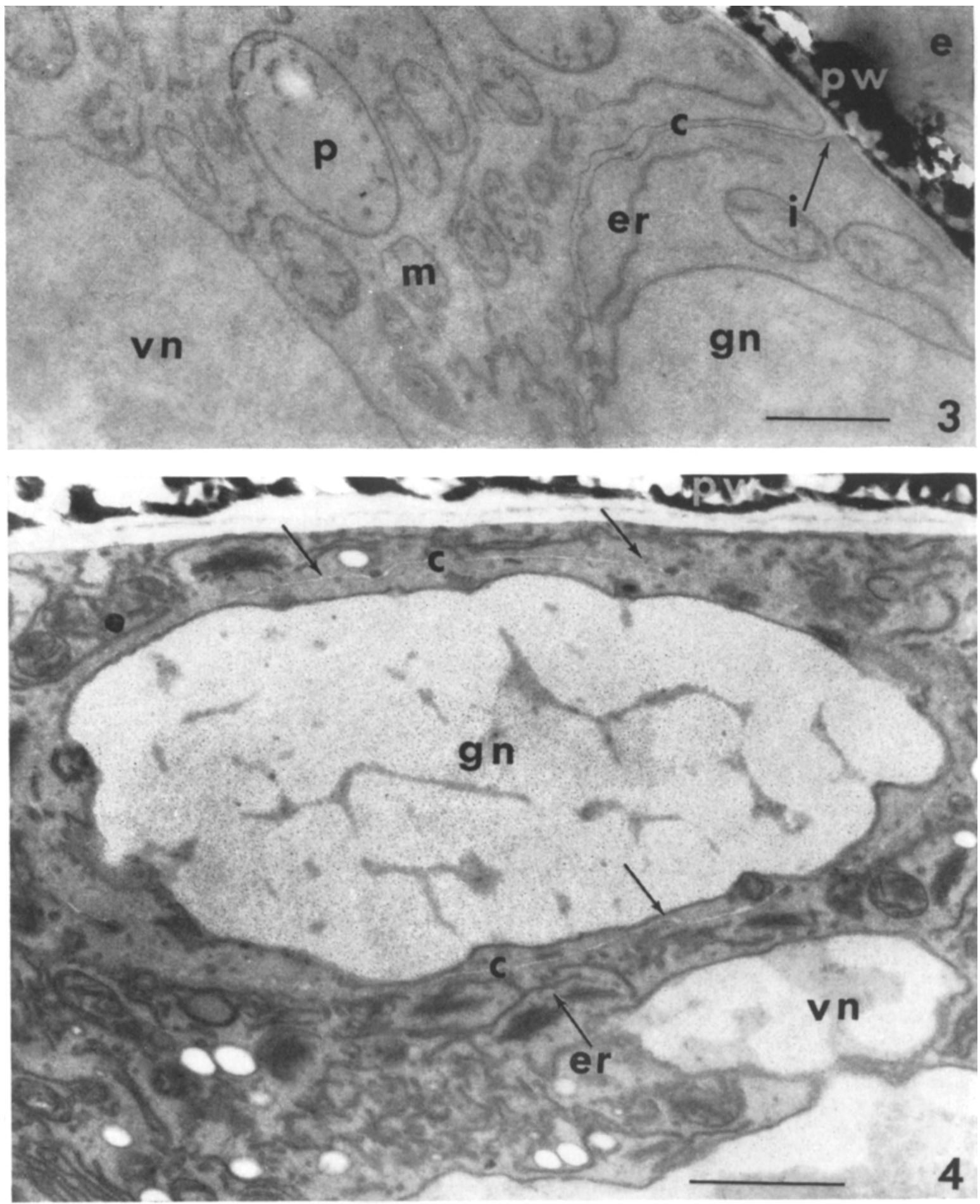

Fig. 3-4.-Fig. 3. Just after completion of the mitosis. The cell wall (c) has elongated and fused with the intine of the pollen wall, as shown at tip of arrow. Note that the intine has an electron density similar to that of the cell wall, and that the plasma membranes of the generative and vegetative cells are continuous with the plasma membrane bordering the intine. $\mathrm{e}=$ exine, $\mathrm{i}=$ intine of pollen-grain wall; $\mathrm{p}=$ plastid. Other symbols as in Fig. 1 and 2 . $\times 21,000 .-$ Fig. 4 . Mature pollen grain from a flower bud whose petals were purple. The cell wall (c) has become detached from the pollen wall (pw), so that the generative cell is embedded at this stage in the vegetative cytoplasm. Note the extremely delicate attenuated cell wall, lying at tips of arrows. $\times 26,000$. 
pollen wall, and the generative cell becomes enveloped completely by the vegetative cytoplasm. The cell wall does not disappear, however, even in the mature pollen grains that are found in open flowers, although it becomes extremely thin (less than $300 \mathrm{~A}$ ), and is obviously narrower than many of the cisternae of the endoplasmic reticulum (Fig. 4).

Discussion AND CONCLUSIONS-In describing our findings, the term "generative cell" has been used, and this implies that the generative nucleus with its surrounding cytoplasm is enveloped by a limiting membrane or layer. Indeed, it has long been known that the generative nucleus is surrounded by a cytoplasmic sheath, which can be seen with the light microscope to differ from the rest of the cytoplasm in stainability (cf. Maheshwari, 1949).

Recent studies also favor the view that there is some kind of membrane or layer between the two nuclei, but the actual existence of a true cell wall has been questioned. Johnstone (1941) observed that the generative nucleus contains a definite sheath of cytoplasm and noted that the cytoplasmic limits of generative and vegetative cells are further differentiated by a clear zone which he regarded as fluid in nature. Hofmeister (1956) studied the plasmolytic nature of the generative cell and concluded that it is bounded by at least a semipermeable membrane. Bopp-Hassenkamp (1960), in examining electron micrographs of osmium-fixed pollen grains of Lilium, found that vegetative and generative nuclei were separated by a pair of osmiophilic membranes bounding a less electron-dense zone of varying thickness. She inferred that this zone did not contain pectin or cellulose and that, accordingly, it was not a true cell wall but merely a bilamellate plasmalemma that separated the two nuclei. Larson (1963), who studied with the electron microscope the fine structure of mature pollen grains of Tradescantia paludosa and a number of other genera and species, reported that no evidence of a cell wall was observed.

Our observations on Tradescantia paludosa point in the other direction and suggest that a true cell wall is present. This is the clear zone between the two electron-dense lines, which we believe represent the plasma membranes of the generative and vegetative cells. The material between the dense layers is continuous at the time of its formation with the intine of the pollen-grain wall, as is clearly shown in Figure 3. Since the intine, which is electron-lucent, gives a strongly positive PAS test, it seems likely that the electronlucent material which connects with the intine is also PAS-positive, although a direct test is difficult because this layer and its associated plasma membranes form a complex whose dimensionsat the outset only 600-700 A and somewhat less thereafter-lie below the resolving power of the ordinary light microscope. But the electron- microscopical evidence and that obtained from the $\mathrm{I}_{2} \mathrm{KI}-\mathrm{H}_{2} \mathrm{SO}_{4}$ test for cellulose seem to provide a reasonable basis for concluding that a true cell wall is present. A similar conclusion has been reached by Sassen (1964), who observed a rigid, cell-wall-like structure surrounding the generative cell in petunia.

Our findings lead in turn to the assumption that the pollen grain of Tradescantia is a multicellular male gametophyte, similar to that of lower groups of plants. The electron micrographs demonstrate that cytokinesis is highly unequal; the generative cell gets only a little cytoplasm, whereas the vegetative cell obtains most of the cytoplasm of the microspore with its included organelles and vacuolar system. The unequal division and the separation of the two cells by a finite cell wall may enable the two nuclei to develop along different pathways within the closed system that is established by formation of the thick, compound pollen-grain coat. Nevertheless, the insularity afforded by a partitioning cell wall does not necessarily preclude the possibility of interaction between generative and vegetative nuclei nor inhibit their capacity to respond in similar manner to environmental variables (as is suggested in the findings of Woodard, 1958, and Takats, 1965).

Summary - A cell wall, presumably containing cellulose and pectin, was observed between the generative and vegetative nuclei in electron micrographs of the pollen grain of Tradescantia paludosa. The cell wall is formed close to the generative nucleus by the fusion of pectin vesicles and is bordered by plasma membranes which become continuous with those of the generative and vegetative cells. The significance of the differential mitosis and of the production of a true cell wall in controlling pathways of differentiation within the closed system of the pollen grain is briefly discussed.

\section{LITERATURE CITED}

Bopp-Hassenkamp, G. 1960. Elektronenmikroskopische Untersuchungen an Pollenschlauchen zweier Liliaceen. Zeitschr. f. Naturforsch. 15b: 91-94.

BECKER, W. A. 1938. Recent investigations in vivo on the division of plant cells. Bot. Rev. 4: 446-472.

Hofmeister, L. 1956. Über die Plasmagrenzschichten im Pollenkorn. Protoplasma 46: 367-379.

Hotchkiss, R. D. 1948. A microchemical reaction resulting in the staining of polysaccharide structures in fixed tissue preparations. Arch. Biochem. 16: 131-141.

Johnstone, G. W. 1941. Cytological studies of male gamete formation in certain angiosperms. Amer. Jour. Bot. 28: $306-319$.

Kaufmann, B. P., H. Gay, J. Buchanan, A. Weingart, E. L. Lahr, V. R. Larsen, and K. Maruyama. 1961 The nature of the materials of heredity. Carnegie Inst. Wash. Year-Book 60: 476-493.

Larson, D. A. 1963. Cytoplasmic dimorphism within pollen grains. Nature 200: 911-912.

LuFT, J. H. 1961. Improvements in epoxy resin embedding methods. Jour. Biophys. Biochem. Cytol. 9: 409-414. 
Maheshwari, P. 1949. The male gametophyte of angiosperms. Bot. Rev. 15: 1-75.

Porter, K. R. and R. D. Machado. 1960. Studies on the endoplasmic reticulum. IV. Its form and distribution during mitosis in cells of onion root-tip. Jour. Biophys. Biochem. Cytol. $7:$ 167-180.

Ris, H. 1955. Cell division, p. 91-125. In B. H. Willier, P. A. Weiss, and V. Hamburger, [eds.], Analysis of development. W. B. Saunders Co., Philadelphia.

Sassen, M. M. A. 1964. Fine structure of germinated petunia pollen, p. 167-168. In H. F. Linskens, [ed.], Pollen physiology and fertilization. North Holland Publishing Co., Amsterdam.
SAx, K. 1935. The effect of temperature on nuclear differentiation in microspore development. Jour. Arnold Arbor. 16: 301-310.

, AND H. W. Edmonds. 1933. Development of the male gametophyte in Tradescantia. Bot. Gaz. 95: 156163.

Takats, S. T. 1965. Non-random nuclear orientation during DNA synthesis in Tradescantia pollen grains. Jour. Cell Biol. (in press).

WOODARD, J. 1958. Intracellular amounts of nucleic acids and protein during pollen grain growth in Tradescantia. Jour. Biophys. Biochem. Cytol. 4: 383-389.

\section{Zeitschrift für Pflanzenphysiologie}

früher

\section{Zeitschrift für Botanik}

Herausgegeben von H. Beevers, Lafayette/Ind., P. Halldal, Göteborg, W. Haupt, Erlangen, D. Hess, Köln, O. Kandler, München, F. Lynen, München, F. Oehlkers, Freiburg/Br., H. Reznik, Münster, P. Sitte, Heidelberg, J. Straub, Köln, S. J. Wellensiek, Wageningen, und M. H. Zenk, München

Schriftleitung: Prof. Dr. P. Sitte, Heidelberg

Vol. 53 (1965). To be published in 5 issues. Price per volume DM 88,-/US $\$ 22.00$ and postage

In order to meet the increasing specialization in the field of scientific Botany, it is planned that the journal "Zeitschrift für Botanik" should concentrate on plant physiology. For this reason the journal's name will be changed beginning with volume 53 (1965) to

\section{Zeitschrift für Pflanzenphysiologie}

The term plant physiology is to be taken in its broadest sense. Topics reaching from fine structure and function to physiology of movements, from plant biochemistry to developmental physiology will be included.

All papers not written in English will be preceded by an extensive English summary. Good quality of photographic reproduction, especially electronmicrographs will be guaranteed. Short communications will be published in the shortest time pos. sible, normally within two months. For full length papers also a short publication time is guatanteed, as this has been the case so far. The publication of book reviews and review papers will be continued.

The editorial board has been extended. Besides former members, Professors Dr. F. Oehlkers and Dr. J. Straub, the following new members belong to the editorial committee: $H$. Beevers (Lafayette/Indiana), P. Halldal (Göteborg), W. Haupt (Erlangen), D. Hess (Cologne), O. Kandler (Munich), F. Lynen (Munich), H. Reznik (Münster/W.), P. Sitte (Heidelberg), S. J. Wellensiek (Wageningen), and M. H. Zenk (Munich).

Please ask for a sample copy free of charge

GUSTAV FISCHER VERLAG • STUTTGART

7 Stuttgart $1 /$ Germany $\cdot$ Postfach $431 \cdot$ Stafflenbergstrasse 36 